\title{
TERMINOLOGY IN AGRICULTURE
}

\author{
Khaitova Gulshan Bahodirovna \\ A Teacher of German-French Department, \\ Foreign Languages Faculty, Bukhara State University, Uzbekistan
}

\begin{abstract}
The article is devoted to the agrarian terminology of the German and Uzbek languages, their formation, linguistic analysis, linguistic and cultural features and their place in the terminological system.
\end{abstract}

Keywords: agrarian, term, terminology, morpheme, lexeme.

\section{Introduction}

Terminology in the field of agriculture is directly related to the ongoing socio-economic processes in society. In today's world, the media is facing huge changes in the agricultural sector in the context of various climate changes, socio-political events, complex economic processes, as well as pandemics. In order to cover these processes, the media regularly "collide" with the terminology of the agricultural sector. That is why we inevitably come across terms related to agriculture in the speech of politicians, journalists, diplomats and even ordinary people.

\section{Literature review}

It should be noted that the use of agricultural terms is one of the most pressing issues today, as its widespread and systematic use in the media due to various climate changes, socio-political events and interstate conflicts shows that this sector is always in the spotlight. In addition to the fact that the terminology of the agricultural sector is used in different texts (discourse), in different situations (contexts), it is natural that it is also used in scientific and technical fields with a tradition of rapid development.

\section{Analysis}

Although the versatility of the agrarian sector is determined by the fact that their corporate interests are not limited, it reflects the linguocultural nature of a particular period and creates the necessary conditions for the historical development of terms that are gradually formed in the national language. In this sense, the importance of agricultural terms in the translation of historical events, the full description of the linguocultural issues, national traditions of a particular people in the translated text is very important. The development and formation of agrarian terms are inextricably linked with the development of socio-economic life forms and reflect the success of socio-political and economiccultural activities.

Linguistic analysis of German agrarian terms has shown that their nominative-functional features are not always the same.

In German agrarian terminology, we can find polysemous terms as well as monosyllabic terms that have absolute and clear semantic boundaries. For example: term "Land" means - 1) ground(yer); 2) aridity (quruqlik); 3) country (mamlakat); 4) region (o'lka); 5) crop area (ekin maydoni).

The term Bauer, subject to the phenomenon of substantivization, is 1) the farmer; 2); farmer 3) builder; 4) cage; 5) manufacturer; 6) including meanings such as foot (chess). Therefore, the ambiguity of one-component terms makes it difficult to understand and translate them correctly, and 
their exact expression is determined by the text and the situation.

It also reflects the nominative-functional concepts of naming agrarian terms. For example: Milchverarbeitung - milk processing; Baumwollanbauer - cotton growing; jäten - to take weeds; Erntezeit is the time of harvest.

At present, due to the rapid development of agricultural sciences, in particular, agricultural technology, new terms and terminological combinations are emerging. The rapid development of terms based on extra linguistic factors requires the regulation (unification) and standardization of terminology.

\section{Discussion}

In order to unify scientific terminology in almost all countries, special terminological commissions have been established, special terminological reference books, multilingual and annotated dictionaries, thesauruses in the field of knowledge are published. This is a long and complicated process, which is becoming increasingly important so that there is no confusion in the understanding of military texts, the correct translation of official documents, and the order of use of words is not violated. In order to increase the prestige of the Uzbek language in the world, to "filter" many foreign terms into the Uzbek language, the President of the Republic of Uzbekistan "On measures to radically increase the prestige and status of the Uzbek language as the state language" 2019 On December 12, 2019, the Department for the Development of the State Language of the Cabinet of Ministers of the Republic of Uzbekistan launched its activities in pursuance of the Decree No. PF5850 of October 21, 2019.

Includes all words and phrases that perform a nominative function for lexical units representing lexicons and concepts related to the agrarian field. That is, the concepts related to the agricultural sector, including planting, care, cultivation, harvesting of agricultural products, agro-techniques, chemicals against pests of agricultural products, poultry, karakul, horse breeding, etc., are among them. It is also necessary to include the names of scientific and technical, authoritative agricultural organizations used in connection with the vocabulary and concepts of the agricultural sector, the language units used in informal communication.

When talking about different branches of lexicon in the field of agriculture, it is appropriate to emphasize, first of all, the terms and lexemes, phrases used in the agricultural system. This includes agriculture, livestock, fisheries, poultry, and so on. industry workers include terms in the form of lexemes and phrases that express general concepts of lifestyle, organization, agrotechnics, buildings, agrotechnical activities.

There are also a number of terms and phrases that are used in certain areas of agriculture and are known to them.

For example: the following terminological units consisting of singular and primitive morphemes can be given as an example: Verbrauch - expenditure; Bewässerung - irrigation; Dunge - fertilizer. Examples of terms with two, three or more components are: landwirtschaftliche Produkte agricultural products; einjährige Anbaukultur - an annual crop type; Nahrungsmittelproduktion is one of them.

\section{Conclusion}

The terms have the characteristics of mono semantics, consistency, structure, persistence, which is characterized by its lack of dyeing, methodological neutrality. The peculiarity of the term is that it is activated in professional, scientific-style texts, characterized by fundamental proportionality, accuracy, conciseness, nominative-functional, specific function, methodological neutrality, 
comprehensive information.

\section{References:}

1. Langenscheidts Großwörterbuch] / [W. Duda u. a.] [5. aufl.]. - Berlin [u. a.] Langenscheidt, 2001.

2. Dubrova Y.Y. Structural and content specificity of multicomponent terms (based on military documents): Avtoref. dis. ... Cand. philol. sciences. -M., 2015 .-- p. 23.

3. Doniyorov R. Some issues of technical terminology of Uzbek language, -T .:, Science. 1977. - p. 144.

4. Grinev-Grinevich S.V. Terminology // Educational. manual for stud. Universities. - M .: Academy, 2008 .-- pp. 11-12.

5. Kozhanov D.A. New approaches to the definition of the essence of the term in cognitivediscursive research // World of Science, Culture, Education, 2008. -№5 (12). - S. 43-47. 4. Grinev-Grinevich S.V. Terminology // Educational. manual for stud. Universities. - M .: Academy, 2008 .-- pp. 11-12.

6. Kozhanov D.A. New approaches to the definition of the essence of the term in cognitivediscursive research // World of Science, Culture, Education, 2008. -№5 (12). - pp. 43-47.

7. Akhmedova Mehrinigor Bahodirovna, "Problems in Translating the Concept of "Spirituality" ", IEJRD - International Multidisciplinary Journal, vol. 6, no. TITFL, pp. 290-295, Apr. 2021.

8. Mehrinigor Bahodirovna Akmedova, "Introduction of the Concepts of "Spirituality" and "Enlightenment" in Jadid Literature", IEJRD - International Multidisciplinary Journal, vol. 6, no. TITFL, pp. 131-136, Apr. 2

9. Rakhmonova D.M. Ways to determine talented children in preschool education 10.5958/2249-7137.2020.01534.7 Academicia: issn: 2249-7137 vol. 10, issue 11, november 2020

10. Rakhmonova D.M. Introducing innovations in The Preschool Education System With Talented Children. Middle European Scientific Bulletin ISSN 2694-9970.

11. Rajabboyevna A. N. Individualization in education and methods of improving teaching the english language //International Journal of Psychosocial Rehabilitation. - 2020. - T. 24. - №. 1. - pp. 91-96.

12. Alimova N. R. IMPROVING TECHNOLOGY OF INDIVIDUALIZATION ON EDUCATION FOR STUDENTS OF TECHNICAL SPECIALTIES IN TEACHING ENGLISH //Theoretical \& Applied Science. - 2019. - №. 12. - pp. 352-355

13. Rajabboyevna A. N. Organization of English Lessons Based on Advanced Pedagogical Techniques //International Journal on Integrated Education. - T. 3. - №. 3. - pp. 41-45.

14. Кулдашова Н.Б. Француз ва ўзбек тилларида спорт терминологиясининг миллиймаданий хусусиятлари. $\mathrm{PhD}$ илмий даражасини олиш учун тақдим этилган диссертация. Б., 2020. -Б. 1-148.

15. Kuldasheva N.B. THEORETICAL VIEW POINTS OF LINGUISTS ON TERMINOLOGY. SOI: 1.1 TAS DOI: 10.15863/TAS International Scientific Journal. Theoretical \& Applied 
Science, p-ISSN: 2308-4944 (print) e-ISSN: 2409-0085 (online) 2019 Issue: 12 Volume: 80. 2019. - P. http://T-Science.org;

16. Hojieva G.S. LINGUVOCULARY PROPERTIES OF ART TERMS (On the example of French and Uzbek languages). International Journal of Progressive Sciences and Technologies (IJPSAT) Volume: 25 No. 1 2021, - P. 09-15. https://ijpsat.ijshtjournals.org/index.php/ijpsat/article/view/2746/1628

17. Gulchehra Hojiyeva. NATIONAL IDENTITY AND LINGUISTICAL ANALYSIS OF TRANSLATION OF ART TERMS IN UZBEK LANGUAGE. Journal of Contemporary Issues in Business and Government. P-ISSN: 2204-1990. Vol. 27, No. 2, 2021. Pages 16511660. DOI: 10.47750/cibg. 2021.27.02.174 https://cibg.org.au/article_9597.html

18. Kuldasheva N.B., Kuldashev A. SOME DIFFERENT DIFFICULTIES IN SPORTS EXERCICES. SOI: 1.1/TAS DOI: 10.15863 /TAS International Scientific Journal. Theoretical \& Applied Science, p-ISSN: 2308-4944 (print) e-ISSN: 2409-0085 (online) Year: 2019 Issue: 12 Volume: 80 Published: 30.12.2019, http://T-Science.org; 